Cinémas

Revue d'études cinématographiques

Journal of Film Studies

\title{
I Lost It at the Movies : Parodic Spectatorship in Hector Babenco's Kiss of the Spider Woman
}

\section{Bruce Williams}

Volume 10, numéro 1, automne 1999

Cinélekta 3

URI : https://id.erudit.org/iderudit/024804ar

DOI : https://doi.org/10.7202/024804ar

Aller au sommaire du numéro

Éditeur(s)

Cinémas

ISSN

1181-6945 (imprimé)

1705-6500 (numérique)

Découvrir la revue

Citer cet article

Williams, B. (1999). I Lost It at the Movies : Parodic Spectatorship in Hector Babenco's Kiss of the Spider Woman. Cinémas, 10(1), 79-94.

https://doi.org/10.7202/024804ar
Résumé de l'article

Le Baiser de la femme araignée, une coproduction internationale représentative du cinéma ayant succédé au cinema novo, remet en question le concept brésilien d'« anthropophagie culturelle », en opérant un retournement des processus d'identification filmique. Élaborée durant les années vingt par Oswald de Andrade, le plus radical des modernistes brésiliens, l'd'« anthropophagie culturelle » suppose l'assimilation de la culture métropolitaine. De son côté, le film de Babenco met en jeu consommation et recyclage d'images. Par le truchement de l'exagération et du camp, on y parodie la lecture classique d'un film de propagande, autorisant une diversité de lectures. Le Baiser de la femme araignée s'inscrit ainsi comme une lecture qui conteste une icône en provenance d'une culture étrangère et qui récupère la propagande pour dénoncer la répression politique en Amérique latine. 


\section{Lost It at the Movies: Parodic Spectatorship in Hector Babenco's Kiss of the Spider Woman}

\section{Bruce Williams}

\section{RÉSUMÉ}

Le Baiser de la femme araignée, une coproduction internationale représentative du cinéma ayant succédé au cinema novo, remet en question le concept brésilien d'u anthropophagie culturelle", en opérant un retournement des processus d'identification filmique. Élaborée durant les années vingt par Oswald de Andrade, le plus radical des modernistes brésiliens, l'" anthropophagie culturelle suppose l'assimilation de la culture métropolitaine. De son côté, le film de Babenco met en jeu consommation et recyclage d'images. Par le truchement de l'exagération et du camp, on y parodie la lecture classique d'un film de propagande, autorisant une diversité de lectures. Le Baiser de la femme araignée s'inscrit ainsi comme une lecture qui conteste une icône en provenance d'une culture étrangère et qui récupère la propagande pour dénoncer la répression politique en Amérique latine.

\section{ABSTRACT}

An international coproduction representative of the post-Cinema novo mainstream, Hector Babenco's Kiss of the Spider Woman reassesses the Brazilian notion of cultural anthropophagy to examine the subversion of spectatcrial identification. While anthropophagy, as envisioned by Oswald de Andrade, the most radical of Brazilian Modernists, consumes metropolitan culture, Babenco's film foregrounds the consumption and reprocessing of images. Through exaggeration and 
camp, the reconfiguration of a propaganda film parodies classical spectatorship and opens doors to negotiated readings of film. Babenco's film offers a contestatory reading of another's cultural icon, re-deploying propaganda to decry the plight of the disenfranchised and the political repression of the Southern Cone.

A movement of radical experimentation, Brazilian Cinema novo parallels other international "new" cinema movements of the late Fifties and Sixties, particularly the French Nouvelle Vague, and looks back to such dialectical processes as those of the Soviet Avant-garde (Johnson and Stam, p. 55-57). Through its often parodic subversion of classical cinema codes, Cinema novo challenges processes of spectatorship and frustrates the notion of identification, at least as defined by theoreticians of classical film practice. From the early experiments of the "aestheticians of hunger" (Rocha, p. 69-71) to the udigrudi (underground) films of the Sixties (Stam, 1988, p. 312-327), Brazilian cinema has sought to redefine the relationship between spectator and spectacle and reassess conventional processes of suture. Despite undisputed international parallels, the roots of Cinema novo's radicalism are not exclusively international inasmuch as they also draw upon Brazil's cultural history. Of specific importance is the notion of cultural cannibalism, or "anthropophagy," developed by Brazilian Modernist writer Oswald de Andrade in his 1928 "Manifesto antropofágico." Anthropophagy, the most radical phase of the Brazilian Modernist movement, repositions and radicalizes Brazil's stance vis-à-vis European metropolitan culture, a tendency extensively examined by Erdmute Wenzel White, who stresses the movement's debt to Dada, Surrealism, and Futurism. In the realm of the cinema, both mainstream proponents of Cinema novo (and its successor, Cinema novo de novo) and those of the marginal udigrudi are anthropophagic in their redefinition of Brazilian cinema's relationship to classical film discourse.

Made some forty-three years following the birth of anthropophagy, yet taking the movement's main metaphor to its ultimate conclusion, Nelson Pereira dos Santos' How Tasty Was My Little Frenchman (Como era gostoso o meu francês, 1971) forces 
the viewer to avoid identification with a single point of view through narrative shifts which are at once allied to and separate from the point of view of the indigenous tribes people depicted. Richard Peña has stressed the independence of Pereira dos Santos' camera at several points in the film from the point of view of any diegetic character, whether European or indigenous (p. 193). Moreover, the film treads slippery turf between newsreel and fiction, frustrating viewer expectations regarding film genre. In Jorge Bodansky's Iracema (1974), such a process is furthered as Godardian devices theatralize the documentary and foster a critical reconsideration of the invasive forces which have prostituted Amazônia, creating what Zuzana Pick terms the construction of a " $[\ldots]$ critical intertext on Brazil's self-image as a nation struggling to enter modernity." (p. 138) Yet although the demise of Cinema novo in the late 1970s and the advent of the era of international coproduction may have squelched considerable cinernatic innovation, the Brazilian filmmaker has continued to challenge and redefine processes of spectatorship. As a case in point, Hector Babenco's Kiss of the Spider Woman (1984) intersects its highly politicized human rights discourse with a parody of Brazil's consumption of European and American film. And this intersection, albeit lacking a primitivist metaphor, is anthropophagic in nature.

An international coproduction representative of the postCinema novo mainstream, Babenco's film reveals how anthropophagy can shed light on Brazilian cinema's subversion of spectatorial identification. While anthropophagy consumes metropolitan culture, Kiss of the Spider Woman parodically foregrounds the consumption and reprocessing of images. This film "consumes" to a unique end generic norms of First World cinema and suggests a model for a national gaze which at once refutes and builds upon conventional modes of spectatorship. Despite the relatively mainstream cinematic discourse chosen by Babenco, Kiss of the Spider Woman fosters a hyper-awareness of identificatory processes as it parodically reassesses the often specious link between screen and memory, sexuality and ideology. Of particular consequence is Babenco's use of camp in the creation of this parody of conventional spectatorship. 
For the purposes of this study, the work of Argentine-born Babenco will be deemed Brazilian inasmuch as the director's most significant works have been created in Brazil. Likewise, for reason of its integral place in a Brazilian cultural / thematic continuum, Kiss of the Spider Woman will be considered a Brazilian film, despite its international cast and use of the English language. Although issues of adaptation are enlightening to the analysis of Babenco's work, space permits only a cursory mention of the relationship between the film and its literary source, the homonymous 1976 novel by another Argentine emigré, Manuel Puig, a comparison which has been convincingly undertaken by Carolyn Pinet.

A brief assessment of key moments in the development of the critical notions of cinematic identification and Brazilian cultural anthropophagy, are in order here. Christian Metz's psychoanalytic discussions in The Imaginary Signifier set the parameters for debates on issues of identification and view the very act of seeing a film as a "[...] complex, multiply connected imbrication of the functions of the imaginary, the real, and the symbolic". (p. 57) Metz argues:

In order to understand the fiction film, I must both "take myself" for the character (= an imaginary procedure) so that he benefits, by analogical projection, from all the schemata of intelligibility that I have within me, and not take myself for him (= the return to the real) so that the fiction can be established as such (= as symbolic): this is "seeming-real." Similarly, in order to understand the film (at all), I must perceive the photographed object as absent, its photograph as present, and the presence of this absence as signifying. (p. 57)

Stressing the interplay between the symbolic and the imaginary implicit in the process of identification, Metz defines the cinema as " $[\ldots]$ a body (a corpus for the semiologist), a fetish that can be loved." (p. 57) Such discussions of identification are inherently linked in film theory to the notion of suture. In her discussion of suture and ideology, Kaja Silverman reminds us of Daniel Dayan's examination of the relationship between this process and ideological coercion. For Dayan, suture forces the 
viewer " $[\ldots]$ to accept certain cinematic images as an accurate reflection of his or her subjectivity and [does so] "transparently' (i.e. it conceals the apparatuses of enunciation)" (Silverman, p. 215). Silverman expands her argument beyond traditional debates on the shot / countershot mechanism by summarizing:

[..] suture is not so much one theory as a group of overlapping theories. Whereas for some theoreticians it can be isolated in the shot / reverse shot formation, for others it is inherent in all of the options which constitute narrativity. However, the theoreticians of suture agree that it provides the agency whereby the subject emerges within the discourse, and (at least ideally) takes up a position congruent with the existing cultural order. (p. 236)

From a feminist perspective, Laura Mulvey's early remarks on visual pleasure, which conceive the spectatrix as a transvestite, have generated over two decades of debate, leading eventually to notions of fluid and multiple spectatorial identifications. Babenco's film, as I will demonstrate, actually parodies Mulvey's arguments in its repositioning of identification and drag.

Turning now to Brazilian cultural anthropophagy, Robert Stam (1989) has argued that the movement is a form of intertextuality, yet one which is set in a context of neocolonial cultural domination. Stam stresses that despite the presence of cannibalist metaphors in Western civilization from Montaigne to the Dadaists, the tendency only became a movement in Brazil. The acme of the anti-colonialist stance of Brazilian Modernism, Oswald de Andrade's "Manifesto antropofágico " radicalized Brazil's search for cultural autonomy and carried the ideals of 1920s experimentation to their most iconoclastic conclusion. Alluding to the Tupinamba Amerindians who injested their enemies in order to assume their strength, Andrade proposes that Brazilian writers and artists consume First World culture, digest it, and create a new product for exportation. Proposing as an alternative to the importation of "canned culture" a matriarchal anarchy devoid of laws and army, the Brazilian anthropophagist is far from isolationist and envisions a continued, albeit reposi- 
tioned exchange between the First World and Brazil. From the diverse "dentitions" of the Revista da Antropofagia to the Tropicalist movement of the late Sixties, anthropophagy has advocated the devouring of metropolitan culture and science and their subsequent reprocessing. While the tendency within the field of Luso-Brazilian studies has been to view anthropophagy from a national perspective and to stress the movement as a rejection of European tradition, Erdmute Wenzel White has emphasized that such movements as Surrealism and Dada provide the anthropophagist with creative processes capable of producing the emancipation of art. Shohat and Stam (1994), moreover, are cognizant of the precarious balance between Brazil and the Continent and have observed the fusion of aesthetic internationalism with political nationalism implicit in the Tropicalist tendency.

Several films of the more radicalized trends of Cinema novo have dealt specifically with indigenous motifs in their cinematic deployment of anthropophogical processes. Together with the aforementioned films by Nelson Pereira dos Santos and Jorge Bodansy, Joaquim Pedro de Andrade's Macunaima (1969) draws most decidedly upon such tendencies to offer a critique of international cultural colonialization and exploitation. Yet if one is to assess the implications of anthropophagy as a cultural attitude for the cinema, it is necessary to determine whether the primitivist motif is essential. Clearly, a film can consume and reprocess metropolitan culture without directly drawing upon cannibalist motifs. Babenco's Kiss of the Spider Woman is exemplary as a film which explores the essence of the movement yet does not depend upon the indigenous metaphor. One encounters here a critique of the consumption and reprocessing of the visual image which debunks cultural colonialization in a manner not unlike primitivist films. Puig's novel, upon which the film is based, further explores the theme of cinematic identification characteristic of the writer's earlier work Betrayed by Rita Hayworth (La traición de Rita Hayworth, 1968). In this novel, Puig foregrounds North American cultural colonization of Argentina through the film medium. To paraphrase comments made by the protagonist of Wim Wenders' Kings of the Road 
(1976), Puig reveals the extent to which the Yanks have colonized the Argentine subconscious. Another film adaptation of a Puig novel, Leopoldo Torres Nilsson's 1974 Boquitas pintadas, draws less explicitly upon narrative cinema as a motif, yet uncontestedly explores the Argentine recoupment of Hollywood norms. Refering to Kiss of the Spider Woman, Carolyn Pinet's perceptive comments argue that much was lost in the "international" adaptation of the novel:

[...] just as Molina had changed and edited the 1940s movies he had seen, so did Babenco change and edit Puig's 1976 text. Vincent Canby and others have discussed the trend to internationalization in movies. Internationalization really means homogenization: that is, more and more, movie directors are bringing together a cast of different nationalities to make a film in English set nowhere in particular about a theme that is universal, supposedly with which we can all easily identify. When the American audience first viewed Kiss of the Spider Woman, what they saw was a film in English with a North American, a Puerto Rican, and a Brazilian playing the main characters, and street signs in Portuguese (the movie was made in Brazil). What they could not see were the streets of Buenos Aires where the novel is set or, given the political situation in Argentina in the early 1980s, a simulation of such a scene. (p. 19)

Although Pinet argues that the Brazilian setting implies for the American audience that all of Latin America is alike, one must recognize, nonetheless, that inasmuch as the São Paulo locations in Babenco's film are never made explicit, they function as an amalgam of urban Latin America centers, as a metaphorical backdrop for the story of political repression which could well transpire throughout the Southern Cone. Pinet further claims that the film oversimplifies and distorts Argentine political reality. Yet does not this very dilution mirror Molina's own editing of the Nazi film whose plot he relates throughout the course of the film to Valentim? One can argue that Kiss of the Spider Woman responds to some of the dilution inherent in the mainstream spectatorial process. 
With regard to the primary diegesis, all historical details are left vague, and we are privy only to Molina's homosexuality and to Valentim's general radical leanings. The embedded films, moreover, reduce the number of intertextual references. While Puig's novel refers to Val Lewton's Cat People (1942), John Cromwell's The Enchanted Cottage (1945), and Jacques Tourneur's I Walked with a Zombie (1943), as well as to what Pinet describes as a "[...] made-up product of German expressionism," and "[...] a Mexican invention, based on Mexican movies of the same period" (p. 21), Babenco retains only the UFA film in its "entirety." In Puig's original Spanish-language novel, the German film is entitled Destino; in the English translation of the novel it is called Her Real Glory. Babenco's Nazi movie, on the other hand, is left untitled. 'Pinet stresses that by choosing to eliminate the American films, Babenco has omitted the theme of the colonialization of Argentine culture by Hollywood (p. 21). Yet Pinet has arguably oversimplified the effects of this choice since such colonialization is implicit in Molina's processes of identification with the heroine of the Nazi movie which overturn and parody conventional Hollywood mechanisms of suture.

The embedded films related by Molina to Valentim, however, contest and parallel the São Paulo sequences of Kiss of the Spider Woman. These films, which superficially function as a mechanism through which the two prisoners cope with the monotony of confinement, are oversimplified and suggest Molina's false memory (or better, misunderstanding) of their implications. Devoid of subplor and textual layering, they are quite distinct from the Hollywood (or German!) ideal. Molina simply (mis)relates those aspects of the films of greatest interest to himself, altering and embellishing the narration so that Valentim can see them as he does. Janet E. Lorenz, for instance, notes that the films Molina relates most likely would have been in black and white, yet "Babenco has filmed them in color, with tones so washed they give the impression of black and white instead, their faint overlay of color perhaps the result of Molina's imagination." (p. 212-213)

Michael Dunne reminds us that Babenco's use of a filmwithin-a-film is both dialogic and self-referential. We as viewers 
in essence watch a film of Molina watching a film " $[\ldots]$ and accept each as a thematic and stylistic comment on the other." (p. 16) Yet the viewer fails to identify completely with the prisoner. Dunne recalls Robert Stam's claims (1989) that a viewer cannot escape from history; contemporary spectators would be hard pressed to lose themselves in a Nazi musical comedy, the knowledge of the holocaust haunting their experience of such a film (p. 43-44). Yet Molina views / recalls from a less privileged vantage point; his enraptured viewing / recollection of the film debunks for the spectator the ideology of suture. Molina, as Dayan has suggested, accepts Leni LaMaison to constitute an accurate reflection of his own subjectivity. Moreover, the film has successfully concealed its apparati of enunciation inasmuch as Molina fails to read it critically or to distance himself from the diegesis.

As protagonist of the embedded film, Leni LaMaison (Sônia Braga) evokes in the viewer a wide range of references to which Molina himself is blind. Although a French chanteuse, she recalls her namesake, Leni Riefenstahl, and the deployment of the woman artist within the Nazi propaganda machine. Perhaps more importantly, Leni anthropophagically repositions the careers of two of the foremost song-birds of the Third Reich, Lale Andersen and Zarah Leander. The former, whose phenomenal rise to success in Nazi Germany was predicated upon her rendition of "Lili Marleen," attempted to exonerate her close involvement in the regime by foregrounding in her autobiography, Der Himmel hat viele Farben (Heaven Has Many Colors, 1972), her love for a Jewish composer and the concentration camp photographs she alleges to have smuggled out of Poland. Like Babenco's chanteuse, Andersen could be deemed the innocent dupe of forces she could not understand. Yet unlike Leni, Andersen collaborated with Jewish organizations "against" the Nazis, or at least as she would have us believe. ${ }^{2}$

Parallels between Leni LaMaison and Zarah Leander are decidedly more marked. Physically, Leni's swarthy appearance and husky voice render her a clone of the Swedish-born singer and star of a wide range of UFA films with ideological stances not unlike that of Babenco's embedded film. Even her song, 
"Quand l'amour se moque de moi" is a mere French adaptation of Leander's hit, "Davon geht die Welt nicht unter," sung in Rolf Hansen's Die grosse Liebe. The scanty plot details Molina successfully recalls of the film - we must remember that he wants Valentim "to see it as he does," and thus edits the diegesis -, could represent an amalgam of several UFA films of the era, yet Leni LaMaison is most decidedly drawn upon Zarah Leander.

The similarities between the two are of particular significance inasmuch as Leander was recouped as a cultural icon by Germany's gay alternative scene in the mid 1980s. ${ }^{3}$ The camp excesses of her acting and demeanor coupled with her husky, sexually-ambivalent voice have rendered her the model of many a drag queen. (We must recall that Pedro Almodóvar integrates into ¿Qué he hecho yo para merecer esto? (What Have I Done to Deserve This?, 1984) a subplot about two Nazi singers in which Leander's music is used.) As Dunne stresses, Leni's campy song is echoed in the final sequences of Babenco's film as it is sung by a drag queen who welcomes Molina back into the gay scene following his parole.

Leander is evoked not only by Leni's appearance, demeanor, and camp, but moreover by the film's tragic situation. We recall Leander has the famous singer in Die grosse Liebe who must suffer the devastating loss of her lover, a heroic fighter pilot in the Luftwaffe, and yet who must still perform on stage. In this case, the source film is devoid of the relationship between a German and an enemy. Despite its deference to Zarah Leander, the unnamed embedded film bears especially marked similarities to a Kirsten Heiberg vehicle, Erich Engels' 1943 Die goldene Spinne (The Golden Spider), which also stars Jutta Freybe, and Harald Paulsen. The film relates the story of two Soviet agents who attempt to infiltrate a German armaments factory. Protagonist Lisawetta, like Leni LaMaison, is a cabaret singer. Yet in this case, she manipulates the affections of a young German engineer to gain access to classified documents. The engineer is ultimately shot and the two Russian spies are arrested. Although the characterization and role of the female protagonist are considerably distinct from those of Leni LaMaison, the entangle- 
ment between a German and a foreign cabaret singer suggests Babenco's embedded film. The iconography of the film, and specifically, a cabaret act in which Heiberg first performs guised as a spider in front of a web and subsequently circulates, like Leni LaMaison, among the patrons of the nightclub, functions intertextually with Babenco's embedded film. We as spectators do not know whether Molina is recalling an actual viewing experience, or rather, is creating his own composite of numerous films. His ability to edit and mis-relate could imply a capacity to add and synthesize. What is obvious through the clarity of his imaginary is that he at one time "did" view one if not several UFA films.

In the Nazi movie Molina relates, musical cues aid in the exaggerated polarization of the film's events and characters. The embedded film opens with a Nazi march based on Lale Andersen's hit tune, "Blaue Nacht am Haven" and we hear Molina describing the entry of German soldiers into Paris. "La Marseillaise," on the other hand, parodically accentuates the efforts of the Resistance workers. Such a facile ideological and political schism, however, fails to account for the split loyalties of Leni LaMaison and her friend, cigarette girl Marianne, the latter an active member of the Resistance. Both women have fallen in love with Germans, despite their love for France. And this love mirrors the primary diegesis, recalling Molina's split loyalties between his growing affection for Valentim and his desire to please the prison officials who have offered him an early release in exchange for information on his cellmate's organization. It further recalls Valentim's own situation, caught between his radical ideology and his love for a bourgeoise.

The Nazi story, closely paralleling the events and situations of the primary diegesis, focuses on Leni's conversion to the Nazi ideal, or to her limited understanding of it, by virtue of the visual image. Lover Werner, chief of German intelligence in Paris, quells Leni's second thoughts on their relationship by showing her a slide show of images of the Third World depicting the misery that will be eradicated by the Nazi cause. And this process is mirrored by Molina's own spectatorial process. Molina, like Leni, is duped by the Nazi film, failing to under- 
stand its true implications and refusing to interrogate the visual pleasure its recalled viewing offers him.

Molina is able to relate only the opening of the second film prior to his departure from prison. He tells of a lonely spider woman on a tropical island prisoner of a web emerging from her own body. Once more, we see Sônia Braga in this role; yet this time, she is joined by Valentim, who appears as a sailor washed ashore on her island. As he gazes longingly at her face, he catches sight of a perfect tear forming in her eye. Although Molina fails to conclude the Spider Woman's story, we return to the island in the final sequence as Valentim dies in the prison infirmary. In his dying delusion, Marta appears at his hospital bed and beckons for him to follow her. They then enter a black and white movie set on the Spider Woman's island. As the lovers run towards the water, the film returns to color and they row away in a small boat. Despite his resistance to and hostility toward the trivial entertainment implied by Molina's films, Valentim takes increasing interest in them, actually requesting Molina to finish the Nazi story and to tell another film prior to his release. The films have actually addressed Valentim's personal situation, his split allegiances closely matched by those of Leni and Marianne.

Of considerably greater importance than the parallel drawn between the diegesis of The Kiss of the Spider Woman and that of the unnamed UFA movie related by Molina is the debunking of traditional assumptions regarding gender and spectatorial identification the presence of the embedded film suggests. Unlike the early claims of feminist theoreticians, Molina as a gay male identifies not with the male protagonist, but with Leni LaMaison, imitating both her dress and gestures. One can argue that he thus reverses Laura Mulvey's model of cross-dressing and female spectatorship. Molina overtly expresses that he identifies with the heroine. Valentim, on the other hand, refuses to discuss his identificatory dynamics, yet reinforces traditional views on male spectatorship in his desire to possess the female. This distinction between the spectatorial processes of the two protagonists is an oversimplification at best and is complicated by the fact that we as viewers are seeing a film they recall / imagine and 
not one they actually view. Given Molina's detailed retelling of his edited version of the story, we initially assume that what we are viewing is his own created or imagined point of view. Leni LaMaison appears to be his private fabrication, one he wishes to transmit to Valentim. Indeed, Sônia Braga's campy extremes appear totally in sync with Molina's drag. When Leni / Molina become the object of Werner's longing gaze in the cabaret, they both become hyper-aware of the objectifying nature of their place in the visual realm. Molina is thus cognizant of his alignment with spectacle rather than with the agent of the look. It is perhaps poetic justice that he, like Leni, dies while attempting to deliver a message for the man he loves, proffering yet another equation, that of spectacle and victim. As we learn of Valentim's back story, however, we soon realize that what we are seeing could well represent "his" imagined reconstruction of Molina's story, for he envisions his lover Marta (also played by Sônia Braga) as Leni LaMaison, and subsequently sees her as the lonely spider woman in Molina's second film. Yet even this explanation of point of view in the embedded film is inadequate. Given Molina's growing affection for Valentim, the use of Sônia Braga in the triple role implies a complex slippage, for if Molina imagines himself as Leni and the Spider Woman, them by implication he has equated himself with Valentim's lover. From the perspective of Babenco's viewer (who is cognizant of the problematic point of view of the embedded films), Molina thus insinuates his way into his cellmate's imaginary! The Nazi movie, an amalgam of various UFA films of the $40 \mathrm{~s}$, is also an amalgam of the imagined viewings / reconstructions of the two protagonists of the primary diegesis.

Paul Julian Smith has defined the cult film as "an adopted child," one which has been uprooted from its original destiny. Molina, in his reinterpretation of the UFA film, demonstrates this process. For Molina, the Nazi films are de-historicized. Absent to him are the film's political and social underpinnings which have now given way to a discourse of drag and camp. As Molina "cultifies" the Nazi films, his viewing is anthropophagic in nature. Like Oswald de Andrade's cultural cannibal, Molina consumes an UFA film, digests and synthesizes those elements 
which please him, and passes those which appear distasteful or confusing. His viewing queers the films that he has reappropriated form the historical context of the Third Reich.

The title of Pauline Kael's 1965 essay anthology, I Lost It at the Movies, suggests a myriad of interpretative strategies applicable to Babenco's film. Implying at once enrapturement and loss of innocence, it speaks to both Molina / Valentim's spectatorial experiences and to those of Babenco's viewer. The men in prison willingly lose themselves in the film, and this loss is sexually charged. Despite Valentim's conscious recognition of the UFA film as a Third World propaganda vehicle, his passion for Marta overcomes his reason, and he sutures himself into the diegetic realm in hope of recouping through the film medium a love that is now lost to him. Molina, on the other hand, loses himself in a contestatory manner. The film for him is a means through which he can cross gender boundaries and celebrate his own desire. Babenco's viewer is considerably more jaded and sophisticated. As Michael Dunne stresses, we cannot view the embedded UFA film in Molina's naive manner because of our inability to escape from history and separate it from the context of the Holocaust. As we view Kiss of the Spider Woman, we too lost "it," this time, the "it" referring to innocence in another sense of the word. Babenco's film makes us hyper-aware of our own mechanisms of identification, of the editorial and synthetic processes of our memory, and of how a text can be reappropriated as "the adopted child" of a new discourse.

Babenco's examination of identification and suturing is anthropophagic in nature. Through exaggeration and camp, Molina's reconfiguration of a propaganda film parodies classical spectatorship and opens doors to negotiated readings of a film; a vehicle touted by a fascist ideology becomes an exploration of desire; a heterosexual love story seeds cross-gendered identification and homoerotic passion. The UFA film is not imported as "canned culture," but rather is re-viewed on Molina's anarchic screen, devoid of the laws and restraints of classical spectatorship. Like Brazilian Modernism which recouped Futurism from the bowels of Fascism and transformed the tendency into a celebration of Brazilian modernity, "Babenco's film offers a contes- 
tatory reading of another's cultural icon, re-deploying propaganda to decry the plight of the disenfranchised and the political repression of the Southern Cone.

\section{The William Paterson University of New Jersey}

\section{NOTES}

1 It is interesting to note that in the Broadway musical, the extremities of the UFA film are replaced by scenes from an invented Soviet film bearing uncanny resemblance to Ayn Rand's novel, We the Living. Protagonist Aurora's campy demise in the play, however, is eliminated in the 1942 Italian film adaptation of Rand's novel by Goffredo Alessandrini, Noi vivi, staring Alida Valli.

2 Lale Andersen's life story, moreover, is indeed material for the cinema. A Humphrey Jennings short of 1944. The True Story of Lili Marlene, rewrites history by claiming that Andersen was imprisoned in a concentration camp. It furthermore confuses Andersen and Leander by calling its protagonist "a little Swedish girl." Fassbinder's 1981 film Lili Marleen repositions Andersen's autobiography in a complex examination of Fascism and spectacle. In a manner not unlike Babenco's film, it draws upon camp and gay sensibility to explore the deployment of excess to political ends.

3 For a better understanding of the role of Zarah Leander as gay icon in Germany, readers can refer to Christian Blackwood's 1986 film, Mein Leben fiir Zarah Leander (My Life for Zarah Leander).

4 The influence of Futurism is particularly clear in Brazilian Modernist poetry. Cases in point are Mário de Andrade's Paulicéia desvairada of 1922 and Murilo Mendes' Poemas of 1930.

\section{WORKS CITED}

Andrade, Oswald de. "Manifesto antropofágico," Obras completas, vol. VI. Rio de Janeiro: Civilização Brasileira (1972), p. 13-19.

Dayan, Daniel. "The Turor Code of Classical Cinema," in Bill Nichols (ed.), Movies and Methods. Berkeley: California (1976), p. 438-451.

Dunne, Michael. "Bakhtinian Diologics in Hector Babenco's Kiss of the Spider Woman." Post Script, vol. 14, n" 3 (1995), p. 14-24.

Johnson, Randal and Robert Stam. "The Theory of Brazilian Cinema: The Filmmakers Speak. Introduction," in Randal Johnson and Robert Stam (eds.), Brazilian Cinema. Austin: University of Texas P'ress (1988), p. 55-57.

Lorenz, Janet E. "Kiss of the Spider Woman," in Frank N. Magili (ed.), Magill's Cinema Annual 1986. l'asadena, CA: Salem (1986), p. 209-213.

Metz., Christian. The Imaginary Signifier. Bloomington: Indiana University Press, 1982.

Mulvey, Laura. Visual and Other Pleasures. Bloomington: Indiana University Press, 1989.

Peña, Richard. "How Tasty Was My Little Frenchman," in Randal Johnson and Robert Stam (eds.), Brazilian Cinema. Austin: University of Texas Press (1988), p. 191-199. 
Pick, Zuzana. The New Latin American Film: A Continental Project. Austin: University of Texas Press, 1993.

Pinet, Carolyn. "Who Is the Spider Woman?", Rocky Mountain Review of Language and Literature, vol. 45, n" 1-2 (1991), p. 19-34.

Rocha, Glauber. "An Esthetic of Hunger," in Randal Johnson and Robert Stam (eds.), Brazilian Cincma. Austin: Universiry of Texas Press (1988), p. 69-71.

Shohat, Ella and Robert Stam. Unthinking Eurocentrism. New York: Routledge, 1994. Silverman, Kaja. The Subject of Semiotics. New York: Oxford University Press, 1983.

Smith, Paul Julian. Desire Unlimited: The Filmis of Pedro Alnodouar. New York: Verso, 1994.

Stam, Robert. "On the Margins: Brazilian Avant-Garde Cinema," in Randal Johnson and Robert Stam (eds.), Brazilian ("inemat. Austin: University of lexas Press (1988), p. 306-327.

Stam, Robert. Subversive Pleasures. Baltimore/London: John Hopkins, 1989.

White, Erdmute Wonzel. Les Amies vingt at Brisil. Le modernisme ot lituant-gatde international. Paris: Editions hispaniques, 1977. 